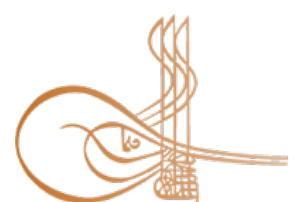

www.turkishstudies.net/social
Turkish Studies - Social Sciences

eISSN: 2667-5617

Research Article / Araştırma Makalesi

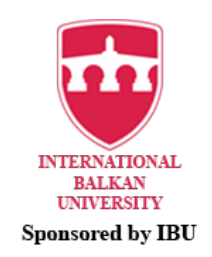

Sponsored by IBU

\title{
Koronavirüs Sonrası Küreselleşme Hareketleri ve Ulus Devletlerin Konumu
}

Globalization Movements and Position of Nation States After Coronavirus

\author{
Eren Alper Y1lmaz
}

\begin{abstract}
Due to the concept of globalization, which has showed its effect in different fields such as economy, transportation, culture, and technology since the early 1990s, new play-makers and decision-makers have emerged in the new world order. Although there has been a global intellection that removes the boundaries, changes the perception of time and space and standardizes individuals, it is unlikely that this notion will gain freedom of movement without the control of nation states. It would not be wrong to claim that after the coronavirus pandemic, which has emerged recently and affected almost all countries in the world, globalization has weakened, the borders have been withdrawn inside and the security measures of the nation states have tightened, therefore trade network over the world has slowed down. Even though the nation state walls seem to be rising in the face of the loss of the impact of globalization on societies in the pandemic process, the survival of nation states depends on the success of their policies for the security and welfare of their citizens in whole of health, economic, psychological and social areas. Nation states should turn the crisis into an opportunity in this period to prevent chaos and uprisings that emerge as a result of social reactions over time. The purpose of this study is to analyze the current and forward-looking position of nation-state structures in the face of globalization, with examples of policies implemented by several states in methods of struggling with pandemics, by emphasizing the loss of power of global actors in the coronavirus process.
\end{abstract}

Structured Abstract: Globalization movements, which have become more effective especially after the Cold War, created a global trade network by facilitating the circulation of goods, services, capital and people in the international arena, removed the boundaries, changed the perception of time and place thanks to the development of technology and transportation, created a cultural and social standardization, brought multinational corporations to the top of the global order as new players. Despite all these developments, it has been observed that global movements have become dominant to the extent permitted by nation-states, and it has been understood that global actors are inadequate in some international cases especially in security-related issues, briefly globalization has some limitations by nation states. According to some authorities, the power of nation states directs globalization, while some opinions argue that globalization weakens the effectiveness of nation states. By referring to the concept of "glocalization", a third view emphasizes that globalization is integrated with local mechanisms, so local and global values take steps together.

Coronavirus, which has recently started in Wuhan, China and spread all over the world, has affected hundreds of thousands of people in different countries, especially in Asian and Central European societies without making distinction between people in terms of income, status, good and bad. Also it has created

\footnotetext{
* Arş. Gör. Dr., Aydın Adnan Menderes Üniversitesi, Söke İşletme Fakültesi, Kamu Yönetimi Bölümü. Res. Asst. Dr., Aydın Adnan Menderes University, Söke Faculty of Management, Department of Public ORCID 0000-0002-5137-4948

Checked by plagiarism software

Published/Yaym: 25 June/Haziran 2020

CC BY-NC 4.0
} 
psychological effects by creating fear and panic among societies. Thus, even though it is late, the states realized that "health safety" is much more important than money, arms and technological developments, so they primarily aimed to develop health policies rather than other areas they invest in. The competence and success levels of the states in the steps taken for struggling with coronavirus will show how long nation states will survive against globalization in the post-pandemic era

In this conjuncture, where globalization movements have weakened and global actors have started to withdraw from the stage, the nation states can turn the crisis into an opportunity and get stronger from the process in some ways; it depends on taking precautions about health conditions and making investment in health sector regarding pandemics as well as carrying out politics to improve the economic, psychological and sociological conditions of the society. Although it is predicted that coronavirus will weaken globalization and strengthen nation states, this process may create an opposite situation if states do not take adequate measures within themselves. In such a critical period, the duty of the nation states to prevent the popular uprisings that may occur at the final stage; to meet the deficits of the citizens losing their jobs by creating a strong economic program, to improve health services and health materials, to keep moral of society high by giving psychological support, to continue controlled production and, if necessary, not to endanger the health of others by imposing criminal sanctions to those who do not obey the rules.

Even though the phenomenon of globalization has accelerated after the Cold War, the study aims to emphasize that the nation states have not been losing their influence, and they are still final decision-makers in the economic, political and social fields. Moreover, study points out the borders have been controlled under protection of nation states for the purpose of security, also the sectors such as international import-export, tourism and transportation, which are the major locomotives of globalization, have been negatively affected by pandemic and dozens of multinational companies have closed their branches and lost money. Therefore, the concept of globalization has lost its importance day by day. The method of the study is mostly literature review. Because the issue is new and popular, internet sources were mostly used in the study involving some statistics, news and speeches.

In conclusion, the main issue is how much nation states could get succeed in fighting against the pandemic as a result of global actors' loss of power via the examples of South Korea, Canada, Italy and Iran, and it is pointed out that the success levels of these policies have significance for nation states to achieve a serious position in the global area. The study focuses on recent pandemic in terms of nation states comparatively and emphasizes that the health aspect of today's condition cannot be considered independent from the other international relations dimension. It should not be forgotten that; nation states are the main actors who should give trust to their citizens mostly in this pandemic process we involve in. On the other hand, they will be the first target by their society when they use their power negatively. That's why, nation states should overcome this difficult process patiently and carry out successful policies in all aspects.

Keywords: Nation State, Coronavirus, Globalization, Pandemic, Security.

Öz: 1990’lı yılların başından günümüze kadar etkisini ekonomi, ulaşım, kültür, teknoloji gibi farklı alanlarda hissettiren küreselleşme kavramiyla birlikte yenidünya düzeninde yeni oyun kurucu ve karar verici mekanizmalar da ortaya çıkmaya başlamıştır. Her ne kadar sınırları ortadan kaldıran, zaman-mekan algısını değiştiren ve bireyleri tek tipleştiren küresel bir anlayış ortaya çıksa da, bu anlayışın ulus devletlerin kontrolü olmaksızın hareket serbestisi kazanması pek mümkün değildir. Son dönemlerde ortaya çıkan ve dünya üzerindeki neredeyse tüm ülkeleri etkileyen koronavirüs pandemisi sonrası da küreselleşmenin zayıfladığını, sınırların içe çekilerek devletlerin güvenlik önlemlerini daha sıkı hale getirdiğini, bu sebeple dünya ticaret ağının yavaşladığını söylemek yanlış olmayacaktır. Pandemi sürecinde küreselleşmenin toplumlar üzerindeki etkisini kaybetmesi karşısında ulus devlet duvarları yükseliyor gibi görünmekle birlikte, ulus devletlerin bu süreçte ayakta kalabilmeleri; onların sağlık, ekonomik, psikolojik ve toplumsal alanların tamamında yurttaşlarının güvenliği ve refahı için izlediği politikaların başarısına bağlıdır. Toplumsal tepkilerin zaman içerisinde yerini kaosa ve ayaklanmalara bırakmaması için ulus devletler bu dönemde yaşanılan krizi firsata çevirebilme becerisi göstermelidirler. $\mathrm{Bu}$ çalışmanın amacı; küresel aktörlerin koronavirüs sürecinde yaşadıkları güç kaybını vurgulayarak, pandemi ile mücadele yöntemlerinde birkaç devletin yürütmüş olduğu politikalardan örneklerle ulus devlet yapılanmalarının küreselleşme karşısındaki mevcut ve ileriye dönük konumunu analiz edebilmektir.

Turkish Studies - Social, 15(4) 
Anahtar Kelimeler: Ulus Devlet, Koronavirüs, Küreselleşme, Pandemi, Güvenlik

\section{Giriş}

Küreselleşme çalışmalarının en popüler teması, kuşkusuz dünyanın bir bütün olarak algılanması ve küresel bir toplumun varlığıdır. Küreselleşme sonucunda dünya küçülmüş, dünyadaki tüm insanlar küresel bir toplum etrafinda "tek bir dünya toplumu" olarak birleşmiş (Albrow ve King, 1990: 9) ve içinde yaşadığımız küresel toplum yalnızca ideolojik bir cemaat olarak değil, aynı zamanda tek bir iktidar ağı olarak algılanmıştır (Mann, 1993: 11). Küreselleşme, sınırları ortadan kaldırmış, zaman ve mekân önemsiz hale gelmiş, mesafeleri daraltmış, insanlar arasındaki iletişim daha kolay ve hızlı kılmıştır. Özellikle iletişim, sermaye, şirketler ve tüketiciler üzerindeki sınırlar kalkmaya başlamış, piyasanın yeni oyuncuları ulus devletlerin güdümünden çıkarak serbestleșmişlerdir. David Harvey'in "zaman-mekân sıkıșması" olarak da kavramsallaştırdığ 1 bu durum, dünyanın "tek bir mekân" olarak küçülmesini, Mc. Luhan'ın tabiriyle de sınırların daralarak "küresel köye" dönüşmesini hızlandırmıştır.

Küreselleşme teorisine katkıda bulunan ana akım araştırmacılar, özellikle de liberalizmi savunanlar, küresel hareketlerin artmasıyla ulus devletlerin çözüldügünü, denetim kapasitelerinin zayıfladığını iddia etmektedirler (Adadağ ve Yıldızcan, 2011: 256). Araştırmacı Fukuyama, "Tarihin Sonu mu?" adlı makalesinde, müreffeh bir yaşam için eskiden beri süregelen beşeri arayışların sona erdiğini, artık özgürlükçü bir yapının ve serbest pazar ekonomisinin hızlanacağını, liberalizmin en ideal yaşam biçimi olarak kendin ispatladığını savunmaktadır (Canbolat, 2012: 50).

Küreselleşme kavramı bazen farklı toplumların birbirine benzeme süreçlerini hızlandırarak tek bir global kültürün ortaya çıkmasını; bazen de toplulukların, azınlıkların ve kimliklerin kendi farklılıklarını ifade etmesini sağlamaktadır. Bir diğer ifadeyle küreselleşme süreci, globalleşen kültürel yapılar ile farklılıkları bir araya getirmekte, kültürel pratiklerin eşzamanlılığı, beraberliği ve birbirlerini tamamlayıcıllı̆g sayesinde aynı zamanda yerelliği ve tikelliği de yaşama geçirmektedir (Keyman ve Sarıbay, 1998).

Soğuk Savaşın sonlarına doğru Berlin Duvarı yıkılmış, milletler arasındaki sınırlar ortadan kalkmış, Doğu ve Batı Almanya halkları uzun yıllar sonra birbiri ile birleşmiştir. 1991'de ise SSCB ve Doğu Bloku'nun çözülmesi, iki kutuplu sistemden tek kutuplu dünya düzenine geçişin habercisi olmuş, eski Sovyet uydu devletleri bağımsızlıklarını ilan etmiştir. Siyasal anlamda evrim geçiren bu süreç, kültürel, teknoloji, iletişim, ulaşım ve ekonomi alanlarında da etkisini göstermiştir. Giddens'ın da vurguladığı gibi (2000: 67) küreselleşme, artan karşılıklı ilişkilerin yalnızca ekonomik anlamda değil, aynı zamanda toplumsal, kültürel ve politik alanlarda da etkili olmasını ifade etmektedir. Batı ülkeleri tarafından yaratılan markalar, değerler ve ürünler tüm dünyada görücüye çıkmış, demokrasi ve özgürlük kavramlarına vurgu yapılmış, serbest piyasa ekonomisi ve rekabetçilik önem kazanmış, çokuluslu şirketler ve uluslararası örgütler yeni aktörler olarak uluslararası arenadaki yerlerini almış, kısacası "Yeni Dünya Düzeni” kavramı ortaya çıkmıştır.

2000'li yıllardan itibaren küreselleşme hareketleri ile birlikte uluslararası firmalar önemli bir fonksiyonu üstlenmekte ve bu firmalar aracılığ ile teknoloji, mal ve hizmetler gelişmiş ülkelerden gelişmekte olan ülkelere doğru yayılmaktadır. Telekomünikasyon, bilgi ve ulaşım teknolojisinde yaşanan hızlı gelişmeler, IMF, Dünya Ticaret Örgütü gibi uluslararası kuruluşların sermayeyi finanse edebilmesi, Microsoft, IBM, Apple, McDonalds gibi çok uluslu şirketlerin çabasıyla mal ve hizmet sektöründe sağlanan liberalleşme hareketleri ekonomik küreselleşmeye zemin hazırlamıştır. Ayrıca ülkelerin hızlı, esnek ve sürdürülebilir bir ekonomik kalkınmayı gerçekleştirme noktasında piyasa ekonomisinin önemini kavramaları da küreselleşme hareketlerini hızlandırmıştır.

Son y1llarda ise teknolojinin günlük hayatta etkisini bir hayli hissettirmesiyle birlikte dünya artık dijitalleşmeye doğru geçmiş, hisse senetleri, döviz işlemleri, mal ve hizmet dolaşımı, bankacılık 
ve borsa işlemleri, hatta kamu hizmetleri bile fiili yazılı alanlar yerine artık, elektronik piyasalar, mobil bankacılık ve e-devlet gibi dijital ortamlarda gerçekleşmektedir. $\mathrm{Bu}$ anlamda küreselleşme, ulusal pazarın ve teknolojinin birleştiği; uluslararası ticaretin yerini e-ticarete bıraktığı; geleneksel devlet modelinde görülen kırtasiyecilik ve uzun bürokrasi işlemlerinin artık e-devlete yetki aktardığ 1 bir sistem ortaya çıkarmıştır. Her türlü mal, hizmet ve kalifiye insan gücünün rekabet koşullarını sağlayacak düzeyde standartlara erişmek için yarıştığ 1 , kamu yönetimi ve siyaset kurumları açısından kendine özgü davranış kalıplarının yaratıldığı bir düzen kurulmuştur (Orhan, 2002: 415).

Son dönemlerde dünya genelinde yaşanan koronavirüs pandemisi, küreselleşme hareketlerinin ve küresel aktörlerin yeniden sorgulanmasına sebep olmuştur. Pandemi karşısında devletlerin kendi içinde önlemler alması, sınırlarını dışarıya kapatması ve uluslararası örgütlerden yeterince destek alamadıklarını iddia etmesi, "Ulus devletler öncülüğünde yeni bir dünya düzeni mi kurulacak?" sorusunu akıllara getirmiştir. Bu bağlamda pandemi ile mücadelede dünya üzerindeki bazı ulus devlet politikaları örneklerini ele almak, küreselin ve yerelin uluslararası düzlemdeki konumlarının daha iyi analiz edilebilmesi açısından literatüre katkı sağlayacaktır.

\section{Küreselleşme Karşısında Ulus Devletler Güçleniyor mu?}

Küreselleşme sonrası devletler tarafından kontrol edilemeyen bireyler arası ilişkiler de sınırları aşmakta ve uluslararası düzeye gelmektedir. Bu sayede bireyler, sivil toplum kuruluşları, uluslararası örgütler, çok uluslu şirketler gibi yapılanmalar da uluslararası arenada ağırlığını hissettiren aktörlerdir (Badie, 2001: 255). Ayrıca çevre, sağlık, ekonomik ve sosyal gelişim, barınma, insan hakları, sürdürülebilir kalkınma, terörizm, göç gibi meseleler de devletlerin sınırlarını aşarak küresel bir nitelik kazanmış, hükümetlerin iç politikalarından ziyade tüm insanlığ uluslararası siyasetin konusu haline gelmiştir.

Yeni sorunların doğmasıyla birlikte yeni aktörler de uluslararası arenada ortaya çıkmış, özellikle güvenlik konuları gerekçe gösterilerek bu aktörlerin daha aktif ve müdahaleci politikalar izlemesi gerektiği üzerinde tartışmalar yapılmıştır. II. Dünya Savaşı sonrasında dünya barışının sağlanması ve savaşların önlenmesi amacıyla kurulan Birleşmiş Milletler gibi uluslararası örgütler kurulmuş, bu örgütler uluslararası hukuk çerçevesinde devletlerin küresel ölçekte atması gereken adımları, tehditlere karşı geliştirilecek olan meşru müdafaa haklarını ve barışı korumanın yollarını belirlemişlerdir. Her ne kadar teorik anlamda uluslararası örgütler hukuki sınırlar çizse de, pratikte savaşlar karşısında yeterince etkili olamamışlardır. Soğuk Savaş'ın bitimiyle ortaya çıkan ve insanlık tarihinde derin izler bırakan Bosna, Kosova ve Ruanda gibi iç savaşlarda Birleşmiş Milletler, bölgelere askeri müdahalede bulunma ve katliamların önüne geçme konularında başarısız bir sınav vermiş; işkence, şiddet ve toplu ölümlere seyirci kalmıştır (Yılmaz ve Akbulut, 2016: 76). BM'nin aksine Kosova gibi iç savaşlarda askeri müdahalede bulunarak bölgeyi işgalden arındıran ABD ve NATO gibi aktörler küresel bir güç olduklarını göstermiş, dünya kamuoyu nezdinde güvenilirliklerini artırmış, böylece devletler ve bölgesel örgütlenmeler karşısında BM gibi uluslararası yapıların rolleri giderek azalmıştır.

Avrupa Birliği kurumları tarafından yapılan kamuoyu yoklamaları, Avrupa'daki ulus devletlerin vatandaşlarının, $\mathrm{AB}$ vatandaşlığına karşı yeterince sempati beslemediğini, ulusal kimliğini $\mathrm{AB}$ kimliğinden daha üstün tuttuğunu göstermektedir. Eurobarameter Raporları'na göre AB'nin 27 üyesinin tamamında yapılan anketlere göre, birlik bünyesinde yaşayan insanların yalnızca \% 23'ü, kendisini "tam anlamıyla Avrupalı" olarak nitelendirmekte, \%24'ü ise Avrupalı olmadığını, kendi ülkelerinin kimliklerine aidiyet hissettiklerini ifade etmektedir. Bu rakamlar neredeyse 5 yıldır birbirine denktir (\%22-\%23-\%24). Fransa, İtalya, İngiltere gibi ülkelerde kendisini Avrupalı olarak görmeyip de, Fransız, İtalyan, İngiliz kimliği ile nitelendirenlerin oran1 \% 40'larda seyretmektedir (European Commission, 2015).

2019 yılında yapılan araştırmada ise her ne kadar kendisini AB vatandaşı olarak hissedenlerin oranında artış görülse de, özellikle bazı ülkelerde bu oran neredeyse yarı yarıyadır. 
Örneğin Bulgarların \%52'si, İtalya ve Yunanistan'ın \%57'si, Birleşik Krallı ve Çek Cumhuriyeti'nin \%58'i, Fransa ve Hırvatistan'ın ise \%64'ü kendisini Avrupalı olarak tanımlamaktadır (Standart Eurobarometer 91, 2019: 16). AB'nin güçlü ülkelerinden Fransa, Birleşik Krallık ve İtalya gibi ülkelerde AB'ye aidiyet hissedenler ile Fransız, İngiliz ve İtalyan hissedenler arasında çok derin bir uçurum yoktur. Ayrıca İngiltere'nin 2016 yılında Brexit süreci adını verdikleri AB'den ayrılma girişimini başlattıkları referandumda, İngiliz halkının \%52'si AB'den ayrılma yönünde oy kullanmış, 4 yıllık geçiş süreci ve yönetimsel aksaklıkların sonunda, 2020 yılının Ocak ayında İngiltere, $\mathrm{AB}$ üyeliğinden ayrılmıştır. İngiltere gibi güçlü bir ülkenin AB'den çıkma kararında ekonomik gerekçeler etkili olduğu kadar, $\mathrm{AB}$ vatandaşlığ tartışmaları da bu süreçte rol oynamıştır.

J. François Bayart'a göre küreselleşme, yeni ve evrenselleşmiş baskı mekanizmalarını yerel aktör ve sistemlerle buluşturmaktadır. Bu süreçte devletler, devlet dışı özel ve uluslararası aktörleri siyasal süreçlere dâhil ederek ve onlara yetki devrederek kendi egemenliğini bir dışa dönüklük üzerinden yeniden pekiştirmektedir (Adadağ ve Yıldızcan, 2011: 14). Ekonomik anlamda bu duruma açıklık getirirsek; serbest pazarların ve çok uluslu şirketlerin kendilerini koruyacak kamu gücü olmaksızın yerel ve küresel seviyede mevcudiyetlerini sürdürmeleri pek mümkün değildir. Her ülkenin güvenlik politikaları dâhilinde yabancı sermayenin, mal ve işgücünün giriş çıkışını kontrol eden bir gümrük sistemi mevcuttur. Bu çerçevede ulus-devletler, yalnızca ülke içi politikaları belirleyen ve uygulayan güç değil, aynı zamanda dış sermayeyi sınıllandırabilen ya da sürdürülebilirliğini sağlayan bir yetki organı olarak görülmelidir. Bunun yanı sıra, üreticiyi ve tüketiciyi iç pazarda yabancı sermayenin ekonomik risklerine karşı koruyabilen ve yerel girişimcilerinin haksız rekabete maruz kalmasını önleyen de yine devletlerdir.

Yabancı sermayeye açık gelişmekte olan ülkelerde güçlü bir devlet yapısının olması gerekmektedir. Aksi takdirde, küresel girişimcilerin iç piyasalarda devletlerden tamamen bağımsız olarak hareket etmesi ve devletin iç ekonomi üzerindeki kontrolü kaybetmesi, vatandaşlar için büyük bir risk oluşturabilir (Bozkurt, 1998:56). Robertson da, her hangi bir ürünün veya küresel pazarlarda kendine yer edinebilmesi için yerel mekanizmaların iznine ve yetkisine tabi olduğunu iddia etmektedir. Buradan hareketle, küreselleşme kavramı yerine küresel ve yereli birleştiren ve yerelin küresel içinde eriyip yok olmadığını gösteren küyerelleşme (glocalization) tanımını literatüre kazandırmıştır (Robertson, 1995). Küresel şirketler yerel pazarlarda tutunabilmek için yine yerel tanıtımlara ihtiyaç duymakta, satış-pazarlama stratejilerini de yerel kültürel değerler üzerinden belirlemektedir. Örneğin, çok uluslu bir şirket niteliğinde olan ve hemen hemen dünyanın her yerinde şubesi olan McDonalds'ın, bazı ülkelerde domuz eti satarken, bazı Müslüman ülkelerde ise Ramazan mönüsü çıkarması ve ürünlerinde domuz eti/yağı kullanmaması, küreselin yereli kendine dâhil edişine örnek olarak gösterilebilir. "Küresel düşün, yerel hareket et" söylemiyle birlikte küyerelleşmenin son yıllarda bir hayli revaçta olduğunu, yerel aktörlerden bağımsız bir küresel sistemin var olamayacağını belirtmek yanlış olmayacaktır.

\section{Koronavirüs Sonrası Küresel Aktörlerin Genel Durumu}

Küreselleşmenin kuşkusuz en tipik olgularından birisi de dolaşım hareketlerindeki artış olmuştur. David Harvey'in "zaman mekân sıkışması" (1989: 5) olarak tarif ettiği küreselleşme hareketleri, kişilerin bir yerden bir yere kalıcı ya da geçici olarak göç etmelerini sağlamıştır. Gerek ulaşım hareketlerinin gelişmesi, gerekse iletişim alanında yaşanan hayatı kolaylaştıran buluşlar, başta insan gücü olmak üzere, malların ve hizmetlerin de dolaşımını sağlamış, sınırlar aşılmış ve mekânsal engeller ortadan kalkmıştır. Hal böyleyken başta Çin, ABD ve Kanada gibi ülkelerde hızlı bir yatırım ağı oluşmuş, yüzlerce çokuluslu şirket; yoğun nüfus, küresel sermayeye açıklık ve tüketim toplumu olma gibi sebeplerden ötürü yatırımlarının büyük kısmını bu ülkelerde yapmayı tercih etmişlerdir. Tekstilden teknolojiye, otomotiv sanayiden gıdaya kadar bir çok şirket mallarını ve hizmetlerini global pazarda görücüye çıkarmış, kapitalizm her alanda olduğu gibi ekonomik alanda da etkisini günden güne göstermiştir. 
Son dönemlerde Çin'in Wuhan kentinde başlayıp pek çok ülkeyi etkisi altına alan ve dünya genelinde 64.000'e yakın kişinin yaşamını yitirmesine sebep olan (https://www.worldometers.info/coronavirus, 2020) koronavirüs, küreselleşmenin hızla gelişen yapısında ters yönde bir etki yapmıştır. Artan vaka sayıları ve yaşanan ölümler, yalnızca insanların beden sağlığını etkilemekle kalmamış, toplumlar üzerinde ekonomik, psikolojik ve sosyolojik etkiler de yaratmıştır. Dünya Sağlık Örgütü'nün (WHO) hızla artan vaka ve ölüm sayısına ve hastalığın hızlı yayılma karakterine bağlı olarak COVID-19'u pandemi olarak ilan etmiş, bu virüsün domino etkisi yaratıp dünya genelinde yayılma ihtimaline karşı tüm ülkeleri acil ve kontrollü sağlık önlemleri almaları için uyarılar yapmıştır. Uluslararası örgütlerin yaptığı uyarılar ve devletlerin almış oldukları tedbirlere rağmen, virüsün etkisi Çin'den başlayıp İran, İtalya, ABD ve Birleşik Krallık'a kadar tüm kıtalarda yayılmış, nüfus, ekonomik güç, askeri veya teknolojik üstünlük ayırt etmeksizin sınırları aşarak küresel bir boyuta ulaşmıştır.

Kısa zamanda farklı coğrafyalara yayılabilmesiyle küresel bir özellik gösteren pandemi, yalnızca insan sağlığını veya sağlık sektörünü olumsuz etkilemekle kalmamış, tekstilden gıdaya, ulaşımdan turizme, enerjiden inşaata kadar birçok sektör üzerinde ciddi bir yıkım meydana getirmiştir. Koronavirüs salgınının yayılma hızını azaltmak için alınan iç ve dış önlemler, küresel ekonomik hareketlere büyük bir darbe vurmuş, böylelikle küreselleşmenin mihenk taşı olan liberal ekonomilerde s1k rastladığımız malların, sermayenin, insanların ve hizmetlerin serbestçe dolaşımı ilkesi ağırlığını yitirmiştir. Son aylarda sınırlar içe çekilmiş, devletler kendi içinde güvenlik amaçlı korumacı ve müdahaleci politikalar izlemeye başlamış, ticari ilişkiler durma noktasına gelmiş, yurtdışından gelen turistlere sınırlar kapatılmış, küresel arenada hâkimiyet kuran pek çok büyük çokuluslu şirket, şubelerini kapatmış ve piyasadan çekilmiştir.

Bazı finans kurumları Çin ve ABD başta olmak üzere ekonomik açıdan güçlü olan ülkelerin ticari engellemeler ve sektörlerin kapanmasıyla beraber ekonomilerinin uğrayacakları kayıplara vurgu yapmıştır. Deutsche Bank, ABD ekonomisinin ilk çeyrekte \% 12,9'luk daralmaya geçmeden önce yalnızca \% 0,6 büyüyeceğini tahmin etmektedir. Buna paralel bir görüş ise Bank of America'dan gelmekte, onlara göre de ABD gayri safi yurtiçi hasılası 2020 y1lının ilk çeyreğinde sadece $\% 0,5$ büyüdükten sonra, y1llık oran bazında $\% 12$ düşerek ikinci çeyrekte çöküşe geçecektir https://markets.businessinsider.com/, 2020). Dünyanın en büyük ikinci ekonomisi olarak gösterilen ve dünya ekonomisindeki payın \%20'sini oluşturan Çin de, koronavirüsün etkisiyle ekonomik açıdan büyük bir düşüş yaşamıştır. Birçok ülke Çin'e ticari sınırlarını kapadığı için, 2020'nin ocak ve şubat aylarındaki sanayi üretimi, bir önceki yılın Ocak-Şubat aylarına göre \%13,5 oranında düşerek beklentilerin çok altında kalmış, ülkenin ihracat oranı bir önceki yıla göre yalnızca ilk 2 ayda \% 17,2 düşmüştür (www.aljazeera.com, 2020). Perakende satışlar bir y1l öncesine göre \% 20,5 düşmüş, çünkü birçok mağaza ay Şubat ayına kadar kapalı kalmış, Mart ayında açılsa da insanlar evlerinden dışarı çıkmadıkları için ürünlere rağbet olmamıştır (www.nytimes.com, 2020).

$\mathrm{Bu}$ süreçte etkilenen en önemli sektörlerden birisi şüphesi ulaşım olmuştur. Müslüman dünyasının her sene akın ettiği hac ve umre seferleri iptal olmuş, yurtdışına çıkışlar yasaklanmış, Türkiye gibi bazı ülkelerde şehirlerarası ulaşıma bile kontroller getirilmiştir. Avrupa'nın prestijli havayolu firmalarından Air France'ın 2020 Mart ayı için resmi olarak açıkladığı uçuş iptali sayısı 3600'ü bulmuş, firma tüm Avrupa'daki ağ kapasitesinin \%25'ini azaltma kararı almıştır (www.barrons.com, 2020). Amerikan şirketi olan Delta Air, uçuşlarının yalnızca \%30'unu yapmakta, United Airlines, planlanan programının yalnızca \% 68'ini eyleme geçirebilmekte, Southwest Airline ise günlük 4.000 uçuşunun 1.500'ünü iptal etmektedir (edition.cnn.com, 2020). Seyahat iptallerinin ve ülkeye özgü uluslararası uçuş kısıtlamalarının toplamının sektöre zararı toplam 880 milyar doları bulmuştur (www.weforum.org/agenda, 2020). Tüm bu süreç, ulaşım firmalarının cirolarının azalmasına -şayet salgın uzun bir süre devam ederse- iflas etmelerine sebep olabilir. 
Pandemi dönemi boyunca yalnızca Çin zarar görmemiş, küreselleşmenin başat aktörlerinden olan çokuluslu şirketler de Çin'de bulunan şubelerini geçici ya da kalıcı kapatma kararı alarak küresel piyasalardaki baskın karakterini yitirmeye başlamışlardır. Starbucks, Çin'de bulunan 4300 şubesinin yarısını kapatma kararı almış, böylece borsada işlem gören hisseleri bir haftada yaklaşık \%8 değer kaybetmiştir. ABD'nin en önemli çokuluslu firmalarının başında gelen teknoloji devi Apple da Çin'de bulunan mağazalarını kapatma kararı almış, küreselleşmenin Mcdonaldlaşma (Ritzer, 2013) olarak da literatürdeki yerini almasını sağlayan McDonald's başta olmak üzere KFC ve Pizza Hut gibi küresel restoran zincirleri de Çin'deki şubelerini geçici olarak kapatmıştır (www.investaz.com.tr, 2020). Özellikle Çin gibi nüfusu yoğun ve teknolojik gelişmelere ilgi düzeyi yüksek bir toplumun ciddi talepleri ile ayakta kalan şirketler, kapanma kararı aldıktan sonra büyük zarar etmişlerdir.

Küresel salgının sonuçları Ortadoğu'da da etkisini bir hayli hissettirmeye başlamış, enerji kaynaklarına olan taleplerin düşmesiyle birlikte petrol fiyatları son 20 yılın en düşük seviyesine inmiştir (www.uikpanorama.com, 2020). Birçok ülke tarafından sokağa çıkma yasağının ilan edilmesi, şehirlerarası ve ülkelerarası ulaşımın durması, kısacası ulaşım sektöründeki durgunluk petrol fiyatlarına da olumsuz yansımıştır. Varil fiyatı 30 dolara kadar düşen petrol, özellikle ülke içindeki en önemli geliri petrolden sağlanan İran (ihracatın \%80'i), Suudi Arabistan, BAE gibi ülkelerin iç piyasalarını vurmuş, bilhassa ABD tarafından uygulanan ambargolarla zaten petrol ihracatında bir süredir kısıtlamalar yaşayan İran'ı finansal açıdan derinden etkilemiştir. Birçok petrol ithalatçısı ülke İran ve diğer Körfez ülkelerinden petrol siparişlerini iptal etmiştir ve bu eğilim giderek artmaktadır. Ortadoğu ülkelerinde mevcut sağlık koşullarının pek de yeterli olmadığını düşünürsek, enerji rezervlerinden gelen gelir azaldığ 1 için sağlık sektörüne yapılacak olan yatırımların da sığ kalma riski vardır, bu da virüsün ülke içinde hızla yayılmasına zemin hazırlayabilir ve daha büyük bir ekonomik çöküşü beraberinde getirebilir.

\section{Koronavirüs Sürecince Ulus Devletler Tarafından Yürütülen Politikaların Kendi}

\section{Konumlarına Etkisi}

Koronavirüs ile mücadelede her ülke, sağlıkla ilgili olarak, vatandaşların gündelik hijyen kurallarına uyması, maske takılması gibi vatandaşların kendilerinin alması gereken standart tedbirlerin yanı sıra, ekonomik ve sosyal hayatı ilgilendiren tedbirler de almaya çalışmıştır. Fakat alınan tedbirler ülkeden ülkeye farklılık göstermiş, bazı ülkeler istihdam konusunda aldığı tedbirlerle ön plana çıkarken, bazı ülkeler de sosyal hayatı sınırlama ve çok miktarda test yapma gibi hastalığın yayılmasını engelleyici tedbirlerle gücünü hissettirmişlerdir. Küresel aktörlerin güç kaybettiği ve küresel sınırların içe çekildiği bu dönemde, ulus devletlerin uygulamış oldukları politikalar, onların krizi firsata çevirebilme ve global dünyanın yeni karar vericileri olabilme noktasında ne kadar başarılı olabileceklerini gösterecektir. $\mathrm{Bu}$ bağlamda bazı devletlerin bu süreçte uyguladığı politikaları incelemek elzemdir.

Koronavirüs ile mücadelede örnek gösterilen ülkelerin başında Güney Kore gelmektedir. Bugüne kadar 234 kayıpla (www.worldometers.info/coronavirus, 2020) bu süreci minimum zararla atlatan Güney Kore'de üst düzey yetkililer, 2015'teki MERS (Orta Doğu Solunum Sendromu) salgınında yaşanılan tecrübelerden ders çıkardıklarını ve koronavirüse karşı önlemlerin erken ve tavizsiz bir şekilde alındığını ifade etmektedirler (www.bbc.com/turkce, 2020). Güney Kore'de alınan önlemlerin başında 17 gün içinde koronavirüs testi geliștirilip ülke çapında geniş bir laboratuvar ağı kurmak olmuştur. Ülke çapında bu amaçla kurulan 96 kamu ve özel laboratuvarlarda test sonuçları 5-6 saat içinde alınmaktadır. Ayrıca Güney Kore'de her gün 20 bin kişiye test uygulanmaktadır ve nüfusa kıyasla şimdilik dünya üzerinde yapılan en yüksek test oranı bu ülkede görülmektedir (www.bbc.com/turkce, 2020). Güney Kore, virüsle mücadele adına iki aylık bir sürede tam 17 bin kişiyi karantina altına almış, böylece virüsün ciddiyetinin boyutunu anlamıştır. Virüse 
yakalanan hastaların hastanelerde karantina altına alınmasından o kişilerin daha önceden görüştüğü ve temas ettiği kişilere de test uygulanmasına kadar, hatta virüse yakalan kişilerin alışveriş yaptığ mağazaların kapatılıp dezenfekte edilmesine kadar ülke çapında yüksek güvenlik önlemleri alınmıştır.

Güney Kore hükümeti, virüsün toplumda daha fazla hasarlara yol açmaması açısından sert tedbirlere de başvurmaktadır. Bu çerçevede virüs semptomu göstermeyen fakat şüphelenilen kişilerden, iki hafta boyunca kendilerini karantina altında tutmaları ve ateşlerini düzenli olarak ölçmeleri istenmiştir. Bununla da yetinmeye yetkililer, şüpheli kişileri gözetlemek için mahallelerde ekipler oluşturmuşlar, bu ekiplerin vatandaşların evlerinde kalmalarını sağlamakla görevlendirilmiştir. Maddi anlamda da yaptırımlar uygulama kararı alan hükümet, karantinaya uymayanlara 2.500 dolar para cezası kesilmiş, ayrıca hazırlanması düşünülen yeni yasa tasarısında kurallara uymayanlara 7.500 dolara kadar para ve hapis cezası verilmesi planlamıştır (www.ntv.com.tr, 2020).

Bu süreçte devletlerin vatandaşlarına karşı şeffaf olması ve bilgileri eksiksiz açıklaması, vatandaşların ulus devletlere olan güvenlerini artıracaktır. Güney Kore Sağlık Bakanlığı her gün kaç kişiye test yapıldığını, kaç kişinin sonuçlarının pozitif çıktığını, kaç kişinin vakadan kurtulduğunu ve kaç kişinin hayatını kaybettiğini kendi halkıyla paylaşmış, verileri saklamamıştır (www.theguardian.com, 2020). Ayrıca teknolojiyi de virüsle mücadelede etkin olarak kullanan Güney Kore hükümeti, vatandaşların cep telefonlarından girip virüsün en çok görüldügü sokak ve mahalleleri görebileceği bir uygulama üretmiş ve böylece halkın o bölgelerden uzak durmaları sağlanmıştır (www.aljazeera.com, 2020). Psikolojik açıdan da halkını düşünen Güney Kore, hastanede yatan hastalar için 7/24 psikolojik destek veren birimler kurarak onların psikiyatristlerle düzenli olarak görüşmelerini sağlamıştır. Bu hizmet, vakayı atlatan kişilerin yaşadığı zorlukları unutması, morallerinin yükselmesi ve tekrardan hayata tutunabilmeleri açısından önemlidir.

Fiziksel kapasitenin artırılmasından teknolojik imkânların seferber edilmesine kadar alının tüm bu önlemler, Güney Kore'de neredeyse salgını durma noktasına getirmiş, ölüm sayısını azaltmıştır. Bu bağlamda, koronavirüsle mücadelede Güney Kore yöntemleri tüm dünyada örnek olarak gösterilmiştir. Bu süreçte Güney Kore'nin hem halkının güvenini kazandığını hem de bu savaşın içinden başarıyla çıktığını söylemek yanlış olmayacaktır.

Bu süreçte Kanada da, sağlıkla ilgili önlemlerin yanı sıra almış olduğu ekonomik tedbirlerle de dünyanın güçlü ekonomilerinden birisi olduğunu göstermiştir. Başbakanı Justin Trudeau, düzenlediği basın toplantısında Kanadalılar için bütçeden 82 milyar dolarlık bir yardım paketinin ayrıldığını ve bu paketin Kanada'nın Gayri Safi Yurtiçi Hasılasının yalnızca \%3'üne tekabül ettiğini, özellikle işleri durma noktasına gelen işadamlarına ve işçilere doğrudan 27 milyon dolar tahsis edileceğini, ekonomik istikrara yardımcı olmak için vergi ertelemelerinin dışında Kanadalı işletmelerin ve hane halklarının likidite ihtiyaçlarını karşılamak için 55 milyar dolara kadar destek sağlayacaklarını ifade etmiştir (globalnews.ca/news, 2020). Bu süreçte ekonomik anlamda ne hane halkını, ne işçileri ne de işletme sahiplerini mağdur etmek istemeyen Kanada, hem milli üretimin durmaması ve ekonomik sürdürülebilirliğin sağlanması, hem de çalışan kesimin hükümete olan güveninin sarsılmaması için son derece rasyonel bir politika izleyerek ekonomik önlem paketlerini ön planda tutmuştur. Ayrıca COVID-19 nedeniyle işini kaybeden insanlar için dört ay boyunca ayda 2.000 dolar ödemeye başlamıştır (www.news4jax.com, 2020).

Sosyal devlet olmanın gerektirdiği "halkın öncelikli ihtiyaçlarını gidermek" anlayışıyla hareket eden Kanada, bakım evlerinde kalan evsiz ve yaşlı insanlar için ise ücretsiz gıda ve ilaç yardımının hızlandırılacağını belirtmiştir. Yine evsizlere hizmet sağlayan bakım evlerinin şartlarının iyileştirilmesi konusunda bir takım düzenlemeler getiren Kanada Devleti, bakım merkezlerindeki personel ve ihtiyaç malzemesi (gıda, tuvalet kağıdı vs) sayısının artırılması, evsizlere yeteri kadar tıbbi maske ve ilaç gönderilmesi, hijyen eğitim verilmesi, psikolojik destek verilmesi vs tedbirler 
alınması kararlaştırılmıştır (www.canada.ca, 2020). Eğitim konusunda da Kanada henüz koronavirüs yayılma göstermeden önce de ciddi tedbirler almış, toplumun önemli bir yüzdesini oluşturan okul çağındaki çocukların sağlığını korumak için adım atmıştır. Bu çerçevede solunum yolu hastalığı belirtileri yaşayan öğrenciler / çocuklar ve personel, okul / çocuk bakımı ortamından evde kalması gerektiği zorunlu tutulmuş, 12 yaş grubuna kadar olan bütün okullarda hijyen eğitimi başlatılmış, uzaktan eğitim programları planlamış, 2 metre sosyal mesafe kurulmasına dikkat edilmesi içi öğretmenlere talimat verilmiş, Koronavirüse maruz kalan çocuklara karşı ayrımcılık yapılmaması için okul yönetimini harekete geçirmiş ve ayrımcılığa maruz kalan tüm çocuklara da psikolojik destek hizmeti vermeye başlamıştır (www.canada.ca, 2020).

Özellikle ekonomik alanda çalışanlarını ve vatandaşlarını mağdur etmemek, onların zararlarını karşılamak adına Kanada hükümetinin almış olduğu önlemler, güçlü bir ekonominin ulus devletlerin vatandaşlarına hizmet etme noktasında ne kadar elzem olduğunu gözler önüne sermiştir. Korona ile mücadelede Kanada da başarı sağlamış, geçirmiş olduğu bu zor günlerde "sosyal devlet" anlayışı ile hareket ederek halkının yanında olduğunu göstermiştir.

Koronavirüsün en sık görüldüğü ve ölüm sayılarının her geçen gün arttığı ülkelerden biri olan İtalya'da ise özellikle yerel yönetimler vasıtasıyla güvenlik önlemleri almış, hatta belediye başkanları sosyal medya üzerinden videolar çekerek ve sokak sokak dolaşarak halkının evden dışarı çıkmamasına vurgu yapmışlardır. İtalya'da alınan tedbirlerin başında, ülke genelinde tüm park ve bahçelerin halkın kullanımına kapatılması, tüm açık hava etkinliklerinin yasaklanması, ikinci ya da yazlık evlere yapılan seyahatlerin yasaklanması, spor müsabakalarının ertelenmesi, okulların ve üniversitelerin geçici süreyle tatil edilmesi, gıda ve içecek satan büfelerin kapatılması gibi kisitlamalar gelmektedir (www.cnnturk.com, 2020). Kuralları ihlal edenlere yüksek para cezaları getiren İtalyan hükümeti, ceza limitini 400 euro ile 3000 euro arası olarak belirlemiştir. Ayrıca açılanan kararnameye göre Covid-19 testleri pozitif çıkmasına rağmen karantinada kalma emrini "kasıtlı olarak ihlal eden" kişiler için 1 ila 5 yıl arasında hapis cezası istenilmiştir (www.independent.co.uk, 2020). İtalya'nın almış olduğu bu önlemler, toplumsal güvenliğin sağlanması için ulus devletlerin bireylerin bazı özgürlüklerini kısıtlanmasının yerinde olacağı algısını da beraberinde getirmiştir. Güvenlik gerekçesi ile devletler, kamusal yararı gözeterek özgürlükleri kısıtlayan eylemlere başvurmakta ve bunu anayasal çerçeveye oturtmaktadır (Neocleous, 2014: 2640).

İtalya ile ilgili diğer bir konu, İtalyan vatandaşların kendilerine yeteri kadar yardım etmedikleri düşüncesiyle Avrupa Birliği'ne sitemde bulunmalarıdır. Bazı İtalyan siyasetçiler ve vatandaşlar, sosyal medyada çektikleri görüntülerde Avrupa Birliğinin koronavirüsle mücadelede kendilerine maddi yardım vermedikleri gerekçesiyle İtalyan bayraklarını yakmışlardır. En fazla ses getiren görüntü ise, İtalya Temsilciler Meclisi Başkan yardımcısı Fabio Rampelli'nin ofisindeki Avrupa Birliği bayrağını indirerek yerine İtalyan bayrağı asması ve "Belki sonra görüşürüz" diyerek Avrupa Birliği'ne tepki göstermesidir (en.news-front.info, 2020). Bu tutum, İtalya'nın ulus devlet modeline döneceğinin, belki de AB'den ayrılmak için İngiltere gibi orta vadede bir referanduma gidebileceğinin sinyallerini vermiştir.

Son olarak koronavirüsle mücadelede ele alınması gereken diğer bir ülke; Batılı ve Asya ülkelerine göre virüse karşı önlem almakta geç kalan ve ölümlerin bir hayli fazla görüldüğü İran'dır. İlk vakanın geç açıklanması ve virüsle mücadeleye geç başlanması hastalığın hızla yayılmasının en büyük etkenlerindendir. İran eski Sağlık Bakanı Hasan Kadızade Haşimi, virüsün ülkedeki varlığıyla ilgili resmi açıklamadan 2 ay önce yetkililere durumu bildirdiğini (www.aa.com.tr/tr, 2020) söylemesine rağmen, İran hükümeti bu uyarılara yeterince kulak asmamış ve yeterli tedbirler almamıştır. İran dini lideri Hamaney, virüse ilişkin olarak bunun böyle büyük bir bela olmadığını vurgulamış, Cumhurbaşkanı Hasan Ruhani ise virüsün ülkede görüldüğü ilan edildikten 4 gün sonra her şeyin eskisi gibi devam edeceğini içeren açılamalar yapmıştır. 
Salgının ilk zamanlarında Tahran Yönetimi, şehirlerin veya mahallelerin karantina altına alınmasını planlamadıklarını duyurmuş, bu durumun Birinci Dünya Savaşı'ndan kalan çağdışı bir uygulama olduğunu vurgulamış, İran Sağlık Bakan Yardımcısı İraj Harirçi ise kendisi virüse yakalanan kadar karantina kararını sert biçimde eleştirmiştir. Ruhani bu durumu Batı'nın İran üzerinde bir oyunu olarak algılamış, "korku tellallığı yapan ve ülkeyi felç etmek isteyen düşmanlara" karşı İran halkını uyarmıştır (www.bbc.com/turkce, 2020). İran ilk zamanlar karantina kararındaki 1srarcılığını sürdürmüş, virüsün ilk yayıldı ̆̆ Kum kenti karantina altına alınmamış, ülke genelinde kafeler, parklar, işyerleri kapatılmamış, İran için dini önemi olan "türbeler" açık bırakılmış, vatandaşların günlük hayatlarına devam etmeleri istenmiştir. Üst düzey bürokratların da virüsten etkilenmeleri ve hayatlarını kaybetmeleri üzerine durumun ciddiyetini anlayan İran hükümeti, virüsün ilk ortaya çıktığı günden yaklaşık 1 ay sonra, yani Mart ayının ikinci haftasında ilk kez Çabahar kentini koronavirüs önlemleri kapsamında karantinaya almış ve şehre giriş-çıkışları yasaklamıştır.

İran'da yayılan virüs, İran'ın yeterli sağlık koşullarının olmadığını da gün yüzüne çıkarmıştır. Dünya Sağlık Örgütü, İran'daki sağlık personeline teşhis kitleri ve koruyucu malzemeleri dağıtmış, bazı uluslararası örgütler de İran'a tıbbi malzeme desteği için harekete geçmiştir. Ayrıca milyonlarca maskenin birkaç hafta önce Çin'e bağışlanmış olmasından ötürü ülkede yeteri kadar maske bulunmadığ anlaşılmıştır.

Sınırların kapanması ve ticari ilişkilerin askıya alınması da İran için ciddi olumsuz etkiler yaratmıştır. İhracatının yaklaşık \%80'ini petrolden karşılayan ve Suudi Arabistan ile birlikte dünyanın önde gelen ham petrol üreticilerinden olan İran, mal ve hizmet dolaşımının kısıtlanması sebebiyle artık dışarıya petrol ihraç edememektedir. Üstüne petrolün varil fiyatının düşmesi ve enerji kaynaklarının elde kalması, İran ekonomisini derinden etkilemiştir. Petrolden elde edilen gelirleri sanayi, sağlık, tarım ve diğer sektörlere yatırım amaçlı kullanan İran, üretim noktasında da tıkanıklık yaşamaktadır. Bu süreçte İran, IMF'ye gönderdiği mektupta, "acil finans paketi" kapsamında IMF'den 5 milyar dolarlık kredi talebinde bulunmuştur (www.reuters.com, 2020). Bu durum İran'ın petrol rezervlerinin eridiğini, kendi milli kaynakları ile halkının sorunlarını çözmekte yetersiz kaldığını ve çaresizlikten küresel finans piyasalarına yöneldiğini düşündürmektedir.

\section{Koronavirüs Sürecinin Ulus Devletlere Gelecekteki Muhtemel Etkileri}

Koronavirüs, kısa vadede devletleri ve toplumları yalnızca sağlık ve ekonomi açısından etkiliyor gibi görünse de, eğer bu hızla yayılmaya devam ederse orta vadede sosyolojik ve psikolojik sorunları da beraberinde getirebilir. Bu sorunların da altında yine çoğunlukla ekonomik gerekçeler yatmaktadır. Bu süreçte kapitalizmin doğasında var olan alışveriş ve tüketim çılgınlığ d durgunlaşmış, AVM'ler, restoranlar, kafeler kapanmış, sosyalleşme ortamları artık yerini ev ortamına bırakmıştır. Ekonomisi güçlü olmayan ülkelerde virüs sebebiyle zarar eden işletmeler ve büyük şirketler personellerinin maaşlarını ödeyemeyecek konuma gelmiş, hatta işten çıkarmalar başlamıştır. Bu kriz sürecinde alınan yarı karantina önlemlerinin ekonomik hayatı büyük ölçüde yavaşlatması sebebiyle birçok ülkede işsizliğin ciddi şekilde yükseleceği öngörülebilir. Hâlihazırda ABD'de işsizlik maaş1 başvurusu yapan kişi sayısı Mart'in üçüncü haftasında 3,3 milyon kişiye yükselmiştir (www.washingtonpost.com, 2020). Bu süreç çözülemezse, ABD’nin İşgücü İstatistik Bürosu'nun (BLS) tahminlerine göre de ABD'de işsizlik oranı ikinci çeyrekte \%3.5'tan \%30'un üzerine yükselecektir (www.stlouisfed.org, 2020). ILO'ya göre de dünyada 1,25 milyar küresel iş gücünün \%38'i salgından en çok etkilenen sektörlerde çalışmaktadır. Bu sektörler gida, perakende ticaret, konaklama ve ulaşım sektörüdür (ILO, 2020: 1).

Virüsün getirdiği ekonomik etkilerin toplumların sosyal ve psikolojik durumlarını da olumsuz etkilemesi kaçınılmazdır. Virüsten önceki dönemlerde de işsizliğin insanları bunalıma, depresyona ve nihai aşamada da intihara sürüklediği gerçeğinden yola çıkarak, bu süreçte virüsün istihdam hayatını olumsuz yönde etkilemesinin insan psikolojisinde derin izler bırakabileceği de 
tahmin edilebilir. Yapılan bir araştırmada, işsizlik nedeniyle dünyada her yıl ortalama 45 bin kişinin intihar ettiği ve 2008 krizinden sonra işsizlikle ilişkili intiharların önceki dönemlere göre 9 kat daha fazla arttığı belirtilmektedir (Nordt ve ark., 2015: 240). Şayet koronavirüs de 2008 krizi kadar büyük bir etki yaratırsa önümüzdeki süreçte psikolojik rahatsızlıkların ve intihar oranlarının daha fazla olması kuvvetle muhtemeldir.

Ekonomik sorunlar psikolojik vakaları, psikolojik vakalar ise sosyolojik sorunları beraberinde getirmektedir. Virüsün hat safhalara ulaşmasıyla yaşanılan işsizlik sürecinin getirmiş olduğu psikolojik yıkım; parasızlık, çaresizlik ve hayatta kalabilme gayesi gibi sebeplerle bireyleri hırsızlık, yağmacılık, rüşvet gibi illegal yollara başvurmaya itebilir. Aylardır parasını alamayan ya da işten çıarılan bir bireyin, toplumsal huzuru kaçıran ve kamu düzenini bozan eylemlere başvurması rasyonel bir durumdur. Ayrıca böyle durumlarda insanların birbirine karşı olan mesafeli duruşları Thomas Hobbes'in da "İnsan insanın kurdudur" sözüyle vurguladığı güvensizlik, bencillik, rekabet ve çatışma gibi durumları getirebileceği gibi; insanlardan kaçma, asosyallik ve iletişime kapalılık gibi izolasyonist bir bakış açısını da geliştirebilir. Birbirine güvenmeyen toplumlarda çıkar çatışmaları, anarşi ve illegal yollardan kolay para kazanma en çok rastlanan olumsuzluklardır.

Toplumda yaşanan çıkar çatışmaları, yalnızca bireyler arasındaki ilişkileri değil, aynı zamanda birey-devlet arasındaki ilişkiye de yansıyabilir. Başlangıç noktasından itibaren kısaca değinmek gerekirse; salgın sürecinde kapatılan ve maddi olarak zarara uğrayan işyerleri daha fazla zarar etmemek adına küçülmeye gidebilir, küçülmeye giden şirketlerde işten çıkarmalar, doğal olarak da işsizlik artacaktır. İşsizlik boyutunun hat safhaya ulaşması açlık, yoksulluk ve psikolojik ruh hastalıkları gibi durumları ortaya çıkarabilir. Böyle durumlarda devletinden yardım bekleyen halkın, beklediği desteği alamadığ durumlarda isyana teşvik etmesi kuvvetle muhtemeldir. 2011 y1lında patlak veren Arap Baharı, Tunus'ta tezgâhına el konulan ve ekonomik sıkıntılar yaşayan seyyar satıcı Muhammed Buazizi'nin kendini yakmasıyla başlamış ve domino etkisi yaratarak birçok ülkeye yayılmış, sonuç olarak diktatör rejimlere karşı halk ayaklanmalarını tetiklemiştir (Yılmaz, 2018: 371). Dolayısıyla ekonomik darboğazın bozuk bir psikoloji ile birleştiği nihai noktada devletlere karş1 toplu isyanlar, protestolar başlayabilir. Virüsün başta İtalya olmak üzere Avrupa'da yaygınlaştığını düşünürsek, kapsayıcı ve dikkatli tedbirler alınmadığı sürece yurttaşların devletlerine veya daha genel kapsamda AB'ye karşı güveni zedelenebilir. İtalya'da AB bayraklarının yakılması ve AB'ye sert eleştirilerin yapılması bu güvensizliğin sinyallerini vermektedir. Böyle bir konjonktürde yeni isyan dalgalarının tetiklenmesi ve belki de kabuk değiştirmiş bir "Avrupa Baharı" başlaması ihtimaller dâhilindedir.

\section{Sonuç}

Özellikle Soğuk Savaş sonrası etkisini bir hayli hissettiren küreselleşme hareketleri; serbest piyasa ekonomisi, rekabetçilik, çokuluslu şirketlerin faaliyet alanlarını genişletmeleri ve dünya ticaretinde söz sahibi olmaları vs ekonomik konularda getirdiklerinin yanı sıra, demokrasi ve özgürlük alanlarının genişlemesi, kültürel bir tek tipleşme yaratılması, ulaşım ve teknoloji sayesinde zaman mekân kavramının önemini yitirmesi gibi durumlara da zemin hazırlamıştır. Fakat her ne kadar devletlerin yerini küresel aktörler, yerel alışkanlıkların yerini de küresel değerler alıyor gibi görünse de, aslında ulus devletlerin rolü sanıldığı kadar azalmamış, bilakis uluslararası arenada yaşanan bazı olaylar ulus devletlere önem atfetmiştir. Gümrük girişlerinin ulus devletler tarafindan kontrol edilmesi ve yabancı sermayenin yeri geldiğinde sinırlandırılması, terör olaylarında ulus devletlerin uluslararası örgütlere aldırmaksızın kendi politikalarını yürütmesi, BM gibi uluslararası aktörlerin Bosna ve Kosova gibi bölgesel krizlerde müdahale anlamında yetersiz kalması, son kertede İngiliz halkının referandumla AB'ye karşı tavır alması sonucu İngiltere'nin AB üyeliğinden ayrılması gibi örnekler, ulus devletlerin güç kaybetmediğine yönelik tezlerdir. 
Son dönemlerde dünya genelinde yaşanan koronavirüs, küreselleşmenin etkilerini azaltmış, kamu sağlığı ve güvenliğinin korunması adına ulus devletlerin rollerini ön plana çıkarmıştır. Bu süreçte sınırlar içe çekilmiş, uluslararası ticaret ağı daralmış, uluslararası uçuşlar durmuş, çok uluslu şirketler şubelerini kapatmış, büyük şirketlerin CEO'ları istifasını vermiş, petrol ticareti küresel piyasalardaki dolaşımını yitirmiş, öte yandan her devlet virüsle mücadele edebilmek için kendi içinde sağlık, ekonomi, psikolojik ve toplumsal alanlarda politikalar oluşturarak zor bir sinavdan geçmişlerdir.

Koronavirüsle en etkin şekilde mücadele eden ülkelerin başında, sağlık sektöründe yaptığı yatırımlar, uyguladığı cezai yaptırımlar, vatandaşları bilgilendirme amaçlı olarak seferber ettiği teknolojik imkânlar ve morallerin yükseltilmesi için verdiği psikolojik destek ile Güney Kore gelmektedir. İçinde bulunduğumuz an itibariyle salgını kontrol altına alan Güney Kore hükümeti birçok alanda vatandaşlarının ihtiyacını karşılamış görünmektedir. Kanada da özellikle ekonomik alanda işsiz kalan vatandaşlarının zararlarını karşılamak ve ciddi istihdam bütçesi ayırmak gibi politikalar yürüterek sosyal devlet gibi hareket etmiş, böylece ekonominin bir devletin krizi yönetme sürecinde ne kadar elzem olduğunu göstermiştir. İtalya'da ise özellikle yerel yöneticilerin sokaklarda ve sosyal medya üzerinden seslerini duyurmaya çalışması, nasıl bir seferberlik içerisinde olduğunu göstermiştir. Ayrıca İtalyan siyasetçilerin ve halkının salgınla mücadelede AB'nin yardımlarının yetersiz olmasına karşı gösterdikleri tepkiler, küreselleşme sürecinde supranasyonel kurumların veya "birlik" vurgusu yapan uluslararası örgütlerin zamanla ağırlıklarını yitireceğine, buna karşın ulus devletlerin güç kazanacağına dair tahminleri de beraberinde getirmiştir. İran ise, devletin salgının önemini yeterince idrak edememesi ve geç tedbirler alması sebebiyle, ilk zamanlardaki hızla artan ölüm sayılarını da baz aldığımızda, bu süreçte başarısız bir devlet yapılanması modeli oluşturmaktadır. Üstelik yıllar sonra İran'ın IMF'den borç istemesine istinaden; her ne kadar Güney Kore, Kanada ve İtalya gibi ülkeler salgın ile sıkı bir şekilde mücadele verse de, pandemi sürecinin galibinin kesin olarak ulus devletler olduğunu iddia etmek yanıltıcı olacaktır.

Sonuç olarak salgından etkilenen tüm ülkeler, sağlık kavramının; teknolojiden, silahtan, enerjiden kısaca sermayenin yön verdiği her şeyden daha hayati olduğunu idrak etmiştir. Dolayısıyla bu salgın küreselleşmenin en güçlü silahlarını etkisiz hale getirmiş, küresel sınırların tekrardan çizilmesine ve devletlerin izolasyonist stratejiler geliştirilmesine zemin hazırlamıştır. Artık sınırları ortadan kaldıran; sermayenin, hizmetin ve insan gücünün uluslararası dolaşımını kolaylaştıran, sağlığı ikinci plana atıp maddi gücü öne çıkaran bir küreselleşme anlayışına dönmek uzun bir süre mümkün olmayacak gibi görünmektedir. Lakin bu süreçte, Kanada ve Güney Kore modellerinde görüldüğü üzere ulus devletler de üzerine düşen görevi yerine getirmeli, halkın ekonomik, sağlik, eğitim, gıda, psikolojik vs. temel ihtiyaçlarını karşılayarak toplumda infial yaratılmasına mahal vermemelidirler. Unutulmamalıdır ki; içinde bulunduğumuz bu zor süreçte kendi yurttaşlarına en çok güven vermesi gereken aktörler, ulus devletlerdir; fakat güçlerini olumsuz yönde kullandıkları zaman toplum tarafindan ilk hedef haline gelecek olan da yine onlardır. Küreselleşmenin azalan etkileri karşısında ulus devletlerin tutumu ve eylemleri, krizi firsata çevirebilme yetkinlikleri ve sosyal devlet ilkesinin gereklerini yerine getirebilme kapasiteleri, onların küresel arenadaki konumunu belirleyecektir.

\section{Kaynakça}

Badie, B. (2001).Realism under Praise, or a Requiem? The Praradigmatic Debate in International Relations. International Political Science Review, 22 (3), 253-260.

Bozkurt, N. (1998). Globalleşme ve Devlet. Íktisat Dergisi, 382, 56.

Canbolat, İ. S. (2012). Uluslararası ilişkilerde Türkiye: Savaş ve Barış Arasında Dünya. Aktüel Yayınları. 
European Commission (2015). European Citizenship Report, https://ec.europa.eu/commfrontoffice/publicopinion/archives/eb/eb83/eb83_citizen_en.pdf

Giddens, A. (2000). Üçüncü Yol. Birey Yayıncılık.

Harvey, D. (1989). From managerialism to entrepreneurialism. The transformation in urban governance in Late Capitalism. Geografiska Annaler: Series B, Human Geography, 71(1), 3-17. https://doi.org/10.1080/04353684.1989.11879583

ILO (2020). COVID-19 and the world of work. Second edition Updated estimates and analysis Report,https://www.ilo.org/wcmsp5/groups/public/@dgreports/@dcomm/documents/briefi ngnote/wcms 740877 .pdf.

Keyman, F., Sarıbay, A.Y. (1998).“Küreselleşme, Siyaset ve Toplumsal Yaşam”, Küreselleşme, Sivil Toplum ve İslam (Der. E. Fuat Keyman ve Ali Yaşar Sarıbay). Vadi Yayınları.

Mann, M. (1993). The Sources of Social Power. Vol:2, Cambridge University Press.

Martin A., Elizabeth K. (1990). Globalization, knowledge and society: Readings from International sociology. Sage Publication.

Neocleous, M. (2014). Güvenliğin Eleştirisi. Notabene Yayınları.

Nordt, C., W. Ingeborg, E. Seifritz, W. Kawohl (2015). Modelling Suicide and Unemployment: A Longitudinal Analysis Covering 63 countries, 2000-11. The Lancet Psychiatry, 2 (3), 239245.

Sevinç, O. (2002). "Küresel İktisat Politikaları Olarak Liberalizasyon” (Der. M. Ali Çukurçayır), Küresel Sistemde Siyaset Yönetim Ekonomi. Çizgi Kitabevi.

Robertson, R. (1995). "Glocalization: Time-Space and Homogeneity-Heterogeneity". (Der. Featherstone, M., Lash, S. and Robertson, R.), Global Modernities. Sage Publications.

Yıldızcan, C., Adadağ, Ö. (2011). Küreselleşme ve Demokrasi-Küreselleşmenin Farklı Yüzleri. Dipnot Yayınları.

Yılmaz, E. A. (2018). Uluslararası Örgütler ve Sivil Toplum Kuruluşlarının Türkiye'deki Suriyelilere İnsani Yardımları. Avrasya Uluslararası Araştırmalar Dergisi, 6 (15): 370-382. https://doi.org/10.33692/avrasyad.510057

Yılmaz, E. A., Akbulut, A. (2015). Küreselleşme Sürecinde Ulus-Devletin Rolü Ulus-Devletler Güçleniyor mu. Mehmet Akif Ersoy Üniversitesi Sosyal Bilimler Enstitüsü Dergisi, 8(16), 71-88. https://doi.org/10.20875/sb.47221

\section{İnternet Kaynakları}

https://globalnews.ca/news/6694574/coronavirus-trudeau-economic-measures/, Erişim Tarihi: 19.04.2020.

https://markets.businessinsider.com/news/stocks/us-recession-coronavirus-pandemic-firmsforecasting-economic-distress-predictions-2020-2020-3-1029019597\#4-bank-of-americathe-us-economy-has-fallen-into-recession-4, Erişim Tarihi: 20.04.2020.

https://www.aa.com.tr/tr/dunya/iranda-koronavirusle-mucadelede-basarisizliginnedenleri/1780143, Erişim Tarihi: 18.04.2020.

https://www.aljazeera.com/ajimpact/economic-paralysis-coronavirus-slams-brakes-china-economy200316030817713.html, Erişim Tarihi: 19:04.2020. 
https://www.barrons.com/articles/air-france-will-cancel-3-600-flights-in-march-over-coronavirusits-going-to-get-worse-for-airlines-51583837901, Erişim Tarihi: 18.04.2020.

https://www.bbc.com/turkce/haberler-dunya-51809564, Erişim Tarihi: 17.04.2020.

https://www.cnnturk.com/dunya/italya-koronavirus-kabusu-yasiyor-iste-alinan-yenionlemler?page=1, Erişim Tarihi: 22.04.2020.

https://www.independent.co.uk/news/world/europe/coronavirus-italy-lockdown-police-chargesfines-quarantine-lombardy-a9427046.html, Erişim Tarihi: 18.04.2020.

https://www.investaz.com.tr/blog/corona-korona-virusunun-finansal-piyasalara-etkisi/, $\quad$ Erişim Tarihi: 20.03.2020.

https://www.ntv.com.tr/galeri/dunya/corona-virusle-savasta-guney-kore-modelmi,Pn43VBArQESCdXrZSW3mAA/Q95wLPBt90GolJOms3S-BQ, Erişim Tarihi: 19.04.2020.

https://www.reuters.com/article/us-health-coronavirus-iran-imf/iran-says-it-has-asked-imf-for-5billion-emergency-funding-to-fight-coronavirus-idUSKBN20Z17B, Erişim Tarihi: 05.04.2020.

https:/www.canada.ca/en/public-health/services/diseases/2019-novel-coronavirusinfection/guidance-documents/homelessness.html, Erişim Tarihi: 17.04.2020.

https://www.theguardian.com/world/2020/feb/29/coronavirus-south-korea-cases-surge-as-australiabans-iran-arrivals, Erişim Tarihi: 14.04.2020.

https://www.stlouisfed.org/on-the-economy/2020/march/back-envelope-estimates-next-quartersunemployment-rate, Erişim Tarihi: 14.04.2020.

https://www.weforum.org/agenda/2020/03/this-chart-shows-how-airlines-are-being-grounded-bycovid-19/, Erişim Tarihi: 03.04.2020.

https://www.nytimes.com/2020/03/16/business/coronavirus-china-economy.html, Erişim Tarihi: 29.03.2020.

https://www.uikpanorama.com/blog/2020/03/25/ortadoguda-derinlesen-kriz-koronavirus-dusenpetrol-fiyatlari-ve-yonetilemeyen-ulkeler-meliha-benli-altunisik/, Erişim Tarihi: 02.04.2020.

https://www.washingtonpost.com/business/2020/03/26/unemployment-claims-coronavirus-3million/, Erişim Tarihi: 07.04.2020.

https://edition.cnn.com/2020/03/28/politics/coronavirus-impact-airlines/index.html, Erişim Tarihi: 15.04.2020

https:/en.news-front.info/2020/03/31/maybe-ill-see-you-later-a-senior-politician-from-italy-hasremoved-the-eu-flag/, Erişim Tarihi: 20.04.2020.

https://www.news4jax.com/news/local/2020/04/17/canada-is-already-paying-its-unemployedcitizens-2000-per-month-for-coronavirus-relief/, Erişim Tarihi: 19.04.2020.

https://www.worldometers.info/coronavirus/, Erişim Tarihi: 20.04.2020. 